gre no officers' quarters. When an officer is ill a room has to be borrowed froin the navy. Rooms are badly required for all the different officers on dinty.

The Town Range Hospital is an old infantry barrack temporarily utilised as a non-dieted hospital. Some years ago the building was condemned, and it was also proposed to demolish it and open up a square to improve the ventilation in that part of the town. The position of this non-dieted hospital is bad and the building unsuitable and much closed in by other buildings and walls. It is believed the occupation of this building is but a temporary makeshift; it is used as an overfow to the station hospital. Venereal diseases that do not require dieting are transferred to it, also slight injuries and diseases that do not require nursing. The patients get their barrack rations, namely, $1 \mathrm{lb}$. meat, $1 \mathrm{lb}$. bread, and grocery allowance; the patients are supplied with hospital clothing.

The North Front Hospital is a hutment raised on piles, and very suitable for the purpose. It is chiefly intended for reception of accidents occurring at North Front, which is over two miles distant from the Station Hospital.

What is required is a large dieted hospital to accommodate the total sick of the garrison -300 beds-on a good site, or 6 per cent. of the strength of the troops, which, I believe, is the percentage laid down in the Royal Engineer Synopsis for temperate climates. The hospital should be built on modern lines, with sufficient office and store-room accommodation, and barracks for the Medical Staff Corps close at hand; quarters for the medical officers, quartermaster, and nursing sisters ; wards for sick officers, etc.

In a hospital of the size proposed, with a strength of nearly 5,000 troops, and many married soldiers and their families scattered through the town on the lodging list, a steam disinfecting engine with separate receiving chambers for contaminated and purified clothing is a necessity. Gibraltar is overcrowded, and infectious diseases are of common occurrence. The means should be at hand to limit the spread of such by a rigid system of disinfection. There is a disinfecting apparatus in the Colonial Civil Hospital.

Venereal diseases and simple continued fevers in. ereased considerably in 1893, namely, total admission of all elasses of venereal diseases 1,454 , giving an average constantly sick of 131.75 , this being an increase over 1892 of 126 admissions and 24.00 average constantly sick. The inefficiency from this cause in 1893 amounted to about 52 per cent. of the total average constantly sick from all causes. In former gears inspection of prostitutes and expulsion of those found diseased was, I believe, carried out.

Simple Continued Fever.

An increase took place in 1893 . The predisposing causes

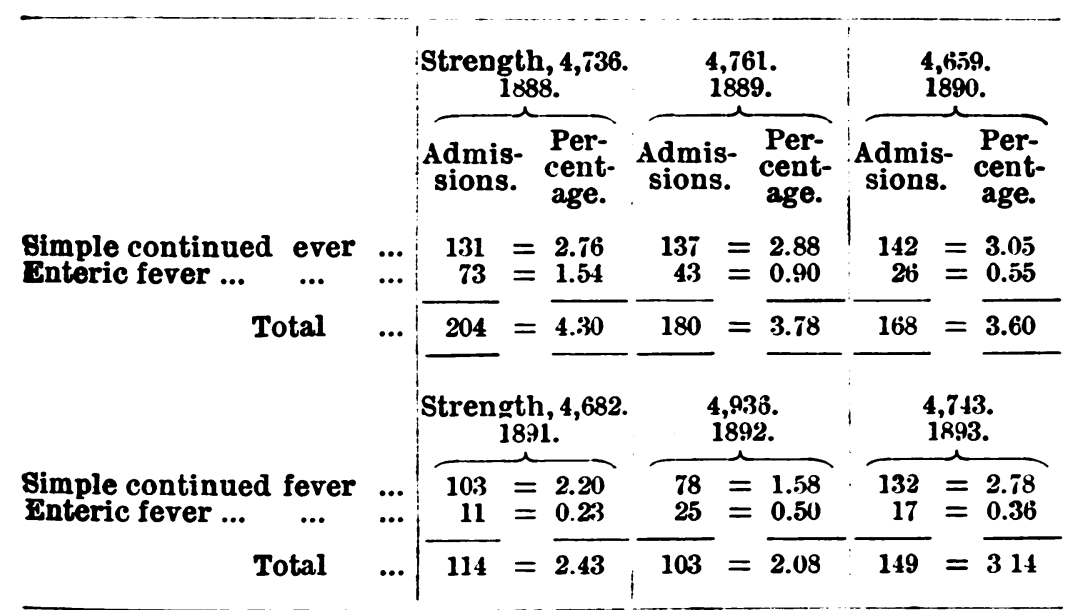

appear to be (1) youth; (2) recent arrival ; and (3) exposure to chills. About half the cases (three weeks' duration and upwards) may be termed typical cases of Rock fever, that is, fever due to faulty sanitation, drain effluvia. Yet the sanitation of Gibraltar is steadily improving year by year, and there is a corresponding improvement in the general health of the community, The milder cases must be attributed to "chills" from incautious exposure and sudden changes of temperature in the hot months, and in former years would have been termed cases of "febricula." During the year referred to, two new regiments, all young soldiers, were of recent arrival in the command; the corps newly arrived always give the largest number of cases during the summer months.

libNes' HaRT.

\section{THE MECCA PILGRIMS.}

\section{BY THE MOULVIE RAFIUdDIN AHMAD.}

"There is due to God from man a pilgrimage unto the House for whosoever is able to find his way there."-AL QURAN, SURA AI IMRAN.

To be asked to give one's views on a burning question, in these columns, is an honour of which any person will feel proud. In this instance, however, duty and honour are happily combined, because I think it a duty, especially when the time of Al Haj, or the annual pilgrimage to Mecca, has drawn so very close, to bring the question of the misery and hardships annually undergone by Moslem pilgrims to the notice of the British and Turkish authorities so far as they are respectively responsible for the protection of life and property and due supervision of the health and comforts of the unfortunate pilgrims.

Disease and Death ayong the Pilgrims.

Last year, as in other previous years, the civilised world, during the period of the pilgrimage, were kept duly informed by Reuter's telegrams of the daily loss of thousands of precious and pious lives owing to the outbreak of cholera and other diseases not altogether beyond the reach of the healing hand of science and the parental care of wise administration. Last year, too, a British sailor, one of the surviving crew of a British vessel carrying pilgrims from Morocco to Jedda, told us a horrible tale of mortality on board his vessel engendered by overcrowding and want of due care on the part of the naval authorities. Not only a very large number of the pilgrim passengers, but also the entire crew, had succumbed to the outbreak of disease. The sailor added that his ship was only one of many others of the kind that meet with a similar fate almost every year, and piteously appealed to the Board of Trade for strict inquiries into this disgraceful state of affairs. About 20,000 lives were lost, chiefly from cholera, last year in the course of a single month. The unfortunate victims, it must be remembered, were the cream of Moslem orthodoxy and piety from different parts of the world.

The Pilgrinage at Pregent an International Danger.

This enormous annual loss of most virtuous and high $y$ precious blood, sustained by Islám, must necessarily weake-1 and prostrate her already exhausted body, and cannot be lookt $d$ upon otherwise than with intense grief and horror by the entire number of her children-nay, by all religious denominations of the world. Because however much Christians and other non-Moslem bodies might differ from us in dogmas, they are bound to admire the strength of conviction, loyalty to principle, and the spirit of self-sacrifice displayed by the Hadjees in such adverse and critical circumstances. But experience has taught us that appeals made merely on moral basis in Europe find responsive sympathy in few brtasts only, and that masses in general are spurred to action only by the expectation of sordid gain, or by fear of immediate harm. I must, therefore, remind $\mathrm{my}$ readers that people of all shades of religious or irreligious beliefs, in all countries, stand exposed to serious dangers of death and disease owing to the annual recurrence of cholera among the Meccan pilto the annual recurrence of cholera among in the prance, Germany, and Russia in 1892 has taught a lesson to European natior s which they are not likely to forget. Of course, I am principally concerned with the well-being of my own co-religionists, and should not have troubled the British press with my remarks at all did it not occur to me that the realisation of my object, as well as theirs, depends in this case on co-operation. As far as their own interests are concerned, the Europeans seldom stand in need of the neighbourly advice of an Asiatic-they are quite able to take care of themselves; but this question is one which tends to prove the interdependence of different nationalities and creeds. 
The immediate scene of action lies under the sovereignty of a powerful Moslem prince, who will naturally be much better influenced by the public opinion of the people of his own persuasion than by the advice of aliens, which has not infrequently proved fatal to his country. Non-Moliammedan efforts towards the right solution of this question are not a little, therefore, dependent upon Moslem co-operation. On the other hand, a very large number of the pilgrims is drawn from Moslems under non-Mohammedan governance, and is conveyed to Arabia by Christian shipowners, principally Englishmen, the great carriers of the world. The grievances of the Hadjees, as passengers, for instance, the overcrowding of the vessels and neglect of sanitary measures on board such vessels, can chiefly be redressed by the British Government, which has control over a very large number of pilgrim vessels. Here the followers of the Prophet are dependent for relief on the support of the British public and the help of other non-Moslem benefactors of humanity.

Public Opinion, Mohammedan and English.

During the last four years this question has been discussed with much zeal and ability in the Mohammedan press. In India, my friend Mr. Mohammad Shahdin, an influential Mohammedan barrister in Lahore, issued an appeal to the Moslems of India, in the columns of the Mohammedan Observer of Calcutta in the year 1891. All enlightened Moslems sympathised heartily with the objects of the eloquent appeal. In Egypt the El Moiyad opened its columns for the discussion of the subject. Anglo-Indian papers of influence called the attention of the Government of India to the grievances of the pilgrims, by means of powerful leading articles. In France, M. Pasteur has been writing in favour of the pilgrims. In England their cause has been ably advocated by Mr. Ernest Hart, the British Medical Journal and several of the English newspapers. Since three years I have been doing what little I can to bring the grievances of the pilgrims to the notice of the responsible authorities.

In November, 1891, the Daily Chronicle published a letter of mine on the subject, and supported the same by extremely sympathetic editorial remarks. The result of this correspondence did some good. The then Viceroy, Lord Lansdowne, happening to be in Bombay, personally inspected a pilgrim vessel. But I have not yet learnt what salutary result followed this Viceregal inspection. I have received a number of complaints and petitions from the Hadjees begging me to do something for them. I drew the attention of Mr. Gladstone some time ago to their grievances, and received aletter of sympathy from him in which the right honourable gentleman expressed a strong hope that the Sultan would do his best for the pilgrims.

During my recent visit to Constantinople and her ruler, I placed the complaints of the pilgrims before Ahmad Jalaluddin Pasha, the Sultan's Aide-de-camp, who promised to submit the same to His Majesty, and let me know His Majesty's reply. I have lately succeeded in forming a committee of enlightened Indian Moslems who have promised me their full co-operation in bringing relief to the suffering pilgrims.

Responsibility of the British GovernMent.

The British Government is responsible for the redress of the following grievances:-Overcrowding of pilgrim vessels ; neglect of sanitary measures on the part of the authorities on board the ship; absence of wholesome food and insafficiency of fresh water supplied to the pilgrim passenger; absence of suitable medical aid (Mohammedan lady patients can only be treated by female doctors, therefore every pilgrim ship must have one male and one female doctor, both understanding at least two Mohammedan languages of the East); absence of suitable lodgings and competent doctors at quarantine stations.

\section{The Koran and the Pilgriysage.}

It has been argued that one of the great difficulties in the way of effecting any improvement in the present system of a voyage to Mecca is the extreme poverty of the pilgrims. It is also said that Islam enjoins every one of her children, be he rich or poor, to repair on a pilgrimage to Mecca. I must, therefore, give here the provisions of the Islamic law upon the subject. The Koran says :-
"There is due to God from man a pilgrimage to the House for whosoever is able to find his way there."

According to Sharah Wikayali (a book much valued by all Sünnis), pilgrimage to Mec(a) is only incumbent upon every Moslem "free, healthy, adult, possessing means of subsistence and conveyance, a little more than what is essentially necessary for the maintenance of himself and his family till his return from the pilgrimage. It is also. necessary that the way or journey should be free from dangers to life and property."

\section{What THE SUltaN SHOULd Do.}

In the opinion of those who have studied the subject, the right solution of this all-absorbing question consists in the appointment of a Commission by H.M. the Sultan, to inquire into and report upon the grievances of the pilgrims. The Commission should essentially be non-political. It should consist of the educated and enlightened representatives of Turkish Moslems as well as a few Moslems belonging to other parts of the Mohammedan world, but acknowledging the caliphate of Abdul Hamid.

Inter alia, the Commission should inquire into the following: The principal sources of cholera in the Holy Land; the burial of the Hesh and blood of animals sacrificed during the Hadj; the condition of latrines and drainage in general ; the purity and sufficiency of water supplied to the pilgrims; the poverty of the pilgrims; the hardship imposed upon pilgrims by enforced quarantine; causes of sickness among pilgrim vessels ; the condition of houses occupied by the Hadjees; cases of extortion and official despotism; the best means of protecting the property of the Hadjees; prevention of dangers to the life and limb of the Hadjees; how to secure safe and comfortable journey to the pilgrims.

But, in order practically to carry out this suggestion, two things are necessary - the consent of His Majesty the Sultan and a sum of money sufficient to defray the expenses of the Commission and to execute its recommendations. The Porte is already beset with a great many pecuniary difficulties, and is hardly in a position to undertake any pecuniary risk. The amount, therefore, must come from those merely interested in the sanitary improvement of Mecca and those interested in the Holy City, historically and religiously.

As a humble admirer of the present Sultan, I may venture to suggest--indeed, if suggestion be necessary to so enlightened a rule-that His Majesty's influence among his spiritual followers beyond his own dominions is pre-eminently a moral one. Anything that tends to diminish this influence among the Moslems necessarily weakens the bond of affection that binds them to his august person. Unfortunately, there are some Mohammedans who dispute the title of the Sultan to the caliphate and watch every opportunity to make His Majesty unpopular by inventing false stories about his indifference to the needs of his spiritual followers. The advisers of the Caliph cannot do better than nail the lies of these malcontents to the counter without delay.

The principal fact thai elevates his position and strengthens the Sultan's claim to the Caliphate is His Majesty's guardianship of the holy shrines. The average Moslem outside Turkey knows very little about the Caliph. He judges the power and the prestige of the Sultan from what he sees of his administration in Mecca and Medina. It is to the interests of the Sultan, therefore, to offer every possible comfort to the Meccan pilgrim.

The Congeqcences of a "Laissez Aller" Policy.

If the present unsatisfactory state of person and property continues in the Holy City for any length of time, the following evils, among others, will surely arise :

The recurrence of the plague in Mecca will diminish the number of the Hadjees. Thousands of persons, otherwise qualified to visit the House of God, will be, in the nature of things, prevented from visiting. The Prophet has forbidden his followers to visit a place infested with cholera (Waba), or to leave a place similarly situated. These people will not only be deprived of the high spiritual blessing, but also of the great temporal advantage which the Hadj indirectly bestows upon the faithful, namely, mutual knowledge, esteem, and affection engendered by personal intercourse. It will diminish commerce and deprive many of the Sultan's 
Arabian subjects dependent upon the pilgrims, of their livelihood. It means also the loss of great moral infuence to the sultan; for the pilgrims, many of whom gre men of high character and educeation, cannot but mark the difference between the system of administration in the dominions of the sultan and that of the country they come from. The contrast, even after making due allowance for all circumstances, must tell unfavourably against the prestige of the greatest Moslem monarch upon earth. The thinking Moslem who visits Arabia, the fountain-head of true religion and the birthplace of the greatest moral teacher of the world, is moved to tears at its present condition. It is in the interests of humanity and Islam, no less than in those of 'Turkey and her ruler, that the insanitary condition of the Moslem holy places, and the hardships which the pilgrims have at present to undergo, should be at once removed. The pilgrims ask nothing but the barest necessaries of human existence and the most essential rights of citizenship, namely, pure air, pure water, and security of life and property. Shall they ask for them in vain?

\section{THE POWERS OF SANITARY AUTHORITIES AS TO ISOLATION AND QUARANTINE.}

THE Wolverhampton board of guardians have recently censured the Willenhall local board in respect of the non-provision of means for the isolation of cases of infectious disease arising in their district. The statement was made at the meeting that as a result of the absence of an isolation hospital, sufferers from small-pox had had to be treated at home, with need as a further consequence for money payments by the guardians to the relatives of the patients, since all the inmates of the infected houses had been prevented by the sanitary authority from earning their living. Unless the compensation thus paid was on account of actual destitution following on the action of the local authority in placing the healthy inmates in "quarantine," we fail to see under what legal power the payments were made. Moreover, if the local board have been thus quarantining healthy persons, under what authority has the course been taken? The facts before us do not make these points clear.

But on the main question at issue we are entirely at one with the Wolverhampton guardians, namely, the cluty of the local board to have been in readiness to secure the prompt isolation of all cases of infectious disease occurring within their district. If, as the facts seem to indicate, the inaction of the local board has in the present instance had the misfortune to pauperise persons by reason of the sanitary authority's insistance on their remaining idle during the progress of treatment at their houses of small-pox cases, then the matter assumes an even more serious aspect.

On the other hand, the powers of local sanitary authorities in respect of hospital provision are ample and full. Under Section 131 of the Public Health Act, 1875, a local authority can provide, either by itself or in combination with one or more adjacent authorities, a hospital for the isolation of cases of infectious disease. Sanitary authorities can also, and preferably, form united districts under Section 279 of the same Act. In many ways the constitution of a joint board under the last-named section is a plan which should commend itself to such local bodies as are desirous of making hospital provision in the best possible manner and in the most economical way. Authorities have an absolute discretion in the matter of the description of hospital to be erected, but they will be well advised if they proceed to the business in a manner calculated to spare overburdening the local rates, and to this end to secure the ready help of the Local Government Board in relation to sanction to a loan for the amount necessary to defray the cost of site and hospital buildings. Willingness to provide a hospital on the lines of the model plans set out in their official memorandum on "Isolation Hospital Provision," at the rate of one bed for each 1,000 of population on a well-chosen site, or at least some smaller beginning, with an administrative building sufficiently large to adapt itself to a hospital afterwards to be extended to such dimensions, will be the truest measure of economy, and by securing the distribution of the cost over a number of years make the burden but little felt. All expe- rience is to the effect that when once a permanent hospital has be'n erected there is but little, and 'ver-decreasing. difficulty in leading people to seek the benefit of its use. liepecially is this the case when, as we would desire to see universal, the institution is free of charge to all comers, who, as matter of fact, are isolated quite as much for the public good as for their own benefit.

In the matter of what we may term "domestic quarantine" we can find no legal power conferring upon a local authority the right to compel healthy persons to submit to the ordeal, nor can we discover the power which permits local bodies to compensate individuals for loss sustained by reason of this quarantine. What we have found, however, is that a Statute of cieorge I, 1721, enacted that in case an infected person quarantined in the pest house " shall actually escape out of such ... house, lazaret, or other place where he or she shall be so placed for performance of quarantine before he or she shall have fully performed the same he or she shall be adjudged guilty of felony and shall suffer death as a felon without benefit of clergy." This statute was repealed by the Statute Revision Act of 1867 . There is, however, no question that sanitary authorities, particularly those having jurisdiction in boroughs, have largely availed themselves of a knowledge of the fact people will ofttimes submit to that for which there is no legal necessity. This method of treatment has, however, no legal standing. and can only be defended on the ground of the end held in view and justified by the docility of the population thus dealt with.

A local board, proceeding on the "Leicester system," would doubtless place itself in a position of difficulty by reason of the absence of power to make money payments to persons who, in response to its request, had voluntarily gone into temporary durance, because of infection of one or more members of their family.

So, too, in the matter of nursing, sanitary authorities often seek to employ trained nurses, in the absence of hospital accommodation, at the homes of the infected sick, only to find that they have exceeded their powers, as, although they can provide nurses and all necessaries in a hospital, they are precluded from doing so outside such an institution. To rely upon the Poor-law authorities for aid in the matter of compensation involves the pauperisation of the working classes; something that should be altogether below the thought of those responsible for the public health. The power of guardians in the matter seems to be limited to cases of destitution, unless the money granted be in the nature of a loan.

One power which sanitary authorities are possessed of is that of providing shelters for households which have to leave their homes on account of necessary disinfection; and, indeed, the provision of such shelters is obligatory when the Infectious Disease (Prevention) Act of 1890 has been adopted. Another very useful power is that of erecting, in connection with the hospital, one or more "quarantine" or observation wards, where cases of doubtful nature can be kept under special notice until the character of the illness is certain. such a measure of precaution will not infrequently be productive of good, not only to the individual in question, but also to the inmates of the ward to which he would otherwise have to be relegated.

We have refrained from touching on the much vexed ques. tion of small-pox isolation, since the difficulties inherent to the safe isolation of this disease have never yet been satisfactorily overcome, and the malady is one calling not only for strict isolation of site, but also for sole use for small-pox of the hospital buildings at a time when that disease is making calls upon the hospital.

A verting is to take place at Salcombe to consider the proposal to erect a memorial to the late Dr. Alfred $H$. Twining.

The Medical Faculty of the Catholic University, Dublin, have nominated Professors Roch and $M$ 'Weeney as their delegates to the International Sanitary Congress at Buda-Pesth.

Medical Magistrates.-Dr. J. J. Hopkins has been appointed a J.P. for co. Galway; Dr. Wr. Delaney and Dr. P. Fointed a J.P each a J.P. for Co. Carlow; Dr. C. J. O. L. Maguire a J.P. for co. Mayo; and Dr. J. Harrington for co. Kerry. 